\section{Ocean mud on Kansai's face}

\section{Osaka}

JAPAN's government as well as its civil engineering contractors are acutely embarrassed that the artificial island meant as the site for the new Kansai International Airport (KIA) here is sinking into the sea at a rate of $5 \mathrm{~cm}$ a month.

Foreign construction companies were turned away from the huge construction project on the grounds (among others) that they lack experience of building on the soft marine sediments around Japan. The same explanation was offered in 1987

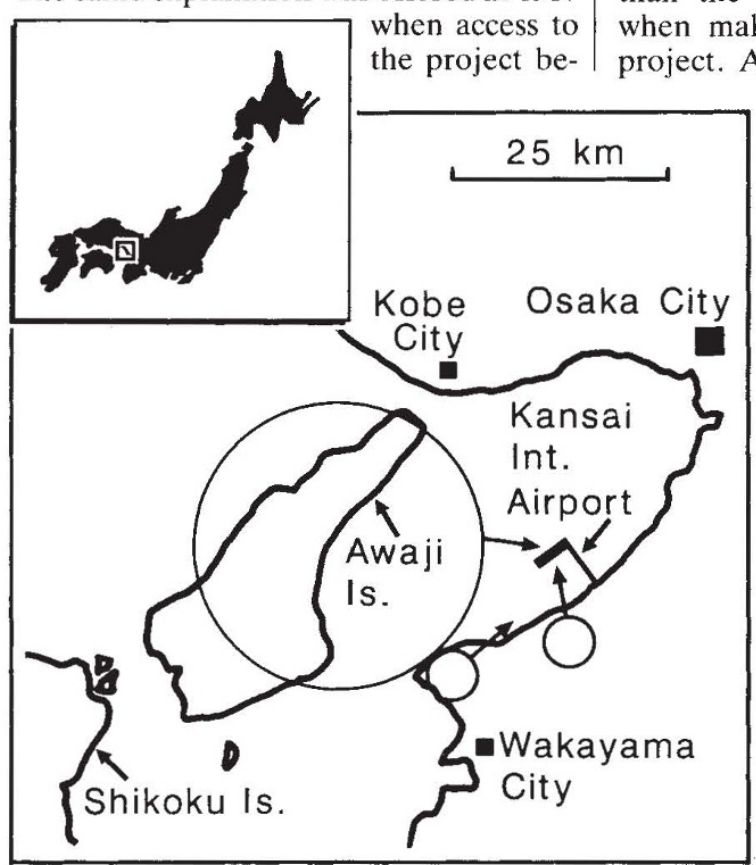

came a major bone of contention in a trade dispute with the United States, Europe and South Korea. The government will now be embarrassed that the island under construction is sinking into soft underlying sediments much faster and further than predicted by the Japanese contractor.

Geotechnical experts and officials of KIA Company Ltd met on 1 September to make more accurate predictions of the subsidence. Details of the meeting have not been made public, but it is clear that several extra metres of fill will have to be added to the emerging island, at a cost of more than $\$ 100$ million, if the airport site is to be sufficiently above sea level.

The reclamation project is of unprecedented scale and involves building an island more than $4 \mathrm{~km}$ long and $1.25 \mathrm{~km}$ wide in 18-20 metres of water $5 \mathrm{~km}$ off the coast. The aim of building at sea was to avoid the problem of aircraft noise in residential areas, so that the airport can operate 24 hours a day.

Work began in 1987 with the construction of a sea wall more than $11 \mathrm{~km}$ long around the site. The soft seabed inside the wall was reinforced to a depth of several metres with pillars of sand before the reclamation operation began early last year.

Three mountains are being excavated on the adjoining mainland and on nearby Awaji Island to fill the site. Every day, 80 huge barges each dump 3,000 cubic metres of rock and rubble at the site in a computer-controlled operation that runs from $4 \mathrm{a} . \mathrm{m}$. in the morning to $11 \mathrm{p.m}$. at night.

By March this year, it was clear that the emerging island is sinking much faster than the KIA company had predicted when making budget estimates for the project. At present the island is sinking about $5 \mathrm{~cm}$ a month and the latest estimates suggest that the total subsidence many years after completion will be about 9-11 metres compared with the $6-8$ metres originally estimated.

The problem is not with the soft surface muds of which Japanese civil engineers claim exclusive knowledge - subsidence of the 20-metre-thick surface layer of clay is likely to be close to the 5 metres or so predicted by the KIA company. But the company's estimate of subsidence of the underlying Pleistocene clay and sand layers seems way out. The company predicted subsidence of only 1-2 metres, but actual subsidence is likely to be $5-6$ metres according to

tween sedimentary particles break and compression becomes much more rapid. The classical model of compression used by the company has proved inadequate, but one developed by KIA's group of geotechnical advisers seems to be more accurate.

Despite the subsidence, KIA officials are determined to open the airport on schedule on 31 March 1993; the company has installed a clock at the site showing the number of days to completion. But because the subsidence will then still be progressing at a fast and uneven rate, the Italian-designed airport terminal building will have to be equipped with compensating hydraulic jacks in its foundations.

Nakase's personal opinion is that the opening of one of the two wings of the terminal (the south wing) should be delayed for two or three years, when the number of hydraulic jacks could be greatly reduced. But KIA officials insist that the airport must be complete in 1993 because the present Osaka international airport cannot cope with the rapid growth in passengers and air cargo and because the company will then have a huge debt of about $¥ 700,000$ million, and the interest payments to go with it.

More generally, Japan is now being criticized for the inadequacy of its international airport facilities, which are effectively shutting foreign airlines out of Japan's lucrative air market.

David Swinbanks

\section{First mud and then mortars}

\section{Osaka}

Ironically, Akio Nakase, emeritus professor of Tokyo Institute of Technology and one of the key advisers for the project, came close to predicting the subsidence correctly in 1987 (see figure), but KIA officials decided to use smaller estimates based on a simpler model because the projected costs of reclamation would be less.

There are two reasons for the discrepancy between the company's estimate and Nakase's 1987 estimate. The Pleistocene layers contain many thin lenses of sand which act as drainage channels for ground water squeezed laterally out of the sediment as the rapidly growing island presses down with a force of about 40 tonnes per square metre. The greater the number of layers, the greater and more rapid the subsidence. The company's estimate assumed only two drainage layers thicker than 3 metres and ignored all thinner layers, while Nakase's calculations included seven drainage layers as little as 1 metre thick.

A second problem is that of estimating the progress of compression of the consolidated Pleistocene sediments. At a certain critical pressure, the bonds be-
Subsidence is not the only problem besetting Kansai International Airport. Last Friday, unprovoked by this correspondent's invitation to the site, radicals opposed to the airport launched a mortar attack on one of the excavation sites for fill. At 3 p.m., nine hours after the mortar attack in the early hours of the morning, a fire was still raging in a nearby forest and a pall of smoke hung over the airport construction site. Eighteen fire engines were needed to put out the blaze.

A man claiming to belong to the radical ultra-leftist organization Chukakuha (middle core faction) claimed responsibility for the attack. Chukakuha has violently opposed the Tokyo International Airport at Narita, making it necessary for the airport to be surrounded by barbed wire and armed guards.

Chukakuha claims to support farmers who were opposed to giving up their land for the airport at Narita. But it is not clear why it opposes the new Kansai airport except that it is calling it the "Narita of the west".

David Swinbanks 